\title{
Występowanie szumów usznych u dorosłych - przegląd piśmiennictwa
}

\section{Tinnitus in adults - literature review}

\author{
Danuta Raj-Koziak \\ Instytut Fizjologii i Patologii Słuchu, Światowe Centrum Słuchu, Klinika Audiologii i Foniatrii, \\ Warszawa/Kajetany
}

Adres autora: Danuta Raj-Koziak, Światowe Centrum Słuchu, Klinika Audiologii i Foniatrii, ul. Mokra 17, Kajetany, 05-830 Nadarzyn, e-mail: d.koziak@ifps.org.pl

\section{Streszczenie}

W ciągu ostatnich kilkudziesięciu lat wiele badań poświęcono częstości występowania szumów usznych, o czym świadczy liczba publikacji dotyczących tego zagadnienia. W niniejszym opracowaniu przedstawiono wyniki tych badań oraz szacunkowe przewidywania na temat nowych przypadków, które pojawią się w przyszłości. Dokładne poznanie skali występowania szumów usznych w populacji osób dorosłych wydaje się istotne, ponieważ liczba pacjentów zgłaszających się po pomoc z powodu dokuczliwych szumów usznych z roku na rok wzrasta. Może to wskazywać, że szumy uszne stają się istotnym problemem ze względu na potrzebę zapewnienia kompleksowej diagnostyki i leczenia pacjentom cierpiącym z ich powodu.

Słowa kluczowe: szumy uszne • częstość występowania • dorośli

\begin{abstract}
The prevalence of tinnitus has been analyzed over the past several decades and it resulted in many publications on this subject. This literature review shows the results of studies concerning the prevalence and incidence of that heterogenous symptom. Accurate identification and determination of the scale of the prevalence and incidence of tinnitus in adults seems to be necessary as the number of patients suffering from it grows rapidly. This suggests that tinnitus has become a significant health problem and real burden to the Health Care System.
\end{abstract}

Key words: tinnitus $\bullet$ prevalence $\bullet$ incidence $\bullet$ adults

\section{Wstęp}

Szumy uszne subiektywne są trudnym problemem pod każdym względem. Nie ma możliwości obiektywnego ich pomiaru, a patofizjologia ich generacji mimo nieustannie prowadzonych badań naukowych nie doczekała się jednoznacznego wyjaśnienia. Ponadto nie wypracowano jednolitego konsensusu diagnostycznego. Liczne metody terapeutyczne stanowią potwierdzenie faktu, że nie ma jednego skutecznego sposobu ich leczenia. Dyskutując o szumach usznych, należy zwrócić uwagę przede wszystkim na te, które są szczególnie dokuczliwe dla pacjentów i znacznie obniżają jakość ich życia. Dokładne rozpoznanie skali występowania szumów usznych w populacji osób dorosłych wydaje się istotne, ponieważ liczba pacjentów zgłaszających się po pomoc z powodu dokuczliwych szumów usznych z roku na rok wzrasta, co może sugerować, że szumy uszne stają się istotnym problemem ze względu na potrzebę zapewnienia chorym kompleksowej diagnostyki i satysfakcjonującego ich leczenia.

\section{Cel}

Celem niniejszego opracowania było przedstawienie częstości występowania szumów usznych u dorosłych na podstawie przeglądu dostępnego piśmiennictwa.

\section{Przegląd wyników prezentowanych w opublikowanym dotychczas piśmiennictwie}

Opublikowane ponad 30 lat temu wczesne wyniki badań na temat szumów usznych, o nazwie United Kingdom National Study of Hearing, to pierwsze badania oceniające częstość występowania szumów usznych w dużej populacji. Przeprowadzone zostały w Wielkiej Brytanii w latach 1980-1986. Swoim zasięgiem objęły grupę 34050 respondentów w wieku od 17 do ponad 80 lat. Kwestionariusze przesłano uczestnikom badania drogą pocztową. Szumy uszne zostały zdefiniowane jako spontaniczne przewlekłe dźwięki, odczuwane w uszach, trwające dłużej niż 5 minut i niepojawiające się bezpośrednio po ekspozycji na głośne dźwięki. W grupie wiekowej od 20 do 29 lat częstość 
występowania szumów usznych wyniosła 5,7\% i stopniowo wzrastała wśród starszej populacji do poziomu 14,4\% w grupie wiekowej od 70 do 79 lat. Powyżej 80. roku życia zaobserwowano spadek odsetka występowania szumów usznych do wartości 13,6\% [1].

Kolejne badania zostały przeprowadzone w Szwecji. W porównaniu $z$ innymi studiami przebadano stosunkowo nieliczną grupę, bo tylko 2556 osób. Szumy uszne zostały określone jako dźwięki w uszach, które występują często lub są odczuwane stale i mają następujące brzmienie: pisk, cykanie, huk oraz szum wiatru między drzewami. Pytania zostały przesłane respondentom pocztą elektroniczną. W grupie wiekowej od 20 do 29 lat występowanie szumów usznych określono na poziomie 7,5\%. Najwyższy odsetek występowania szumów usznych stwierdzono w grupie wiekowej od 70 do 79 lat, w której wyniósł on 21,3\% [2].

W 1990 roku w USA przeprowadzone zostały badania określone jako The United States National Health Interview Survey wśród 59343 wybranych losowo osób. Uczestnicy odpowiadali na pytanie, czy w okresie ostatnich 12 miesięcy odczuwali szumy uszne określone jako dzwonienie lub inne dźwięki w uszach czy w głowie. Częstość odczuwania szumów usznych wzrastała wraz z wiekiem od wartości 5,1\% w grupie wiekowej od 20 do 29 lat do $14,1 \%$ w grupie wiekowej powyżej 80. roku życia [3].

Kolejne badania populacyjne, które przeprowadzono w latach 1994-1995 w USA, to - US National Health International Survey Disability Supplement Study, Phase I. Grupę badaną stanowiło 99435 osób, które poproszono o odpowiedzi na pytania zawarte w kwestionariuszu. Szumy uszne przewlekłe zostały określone jako dźwięki, które mają charakter ciągły od co najmniej trzech miesięcy. Słyszane są obecnie w uszach i brzmią jak dzwonienie, huk czy brzęczenie. W grupie wiekowej od 20 do 29 lat szumy przewlekłe zgłosiło $1,4 \%$ respondentów. Wraz z wiekiem obserwowano wzrost częstości odczuwania szumów usznych aż do wartości 9,4\% w grupie wiekowej od 70 do 79 lat. Począwszy od 80. roku życia, zanotowano zmniejszanie się odsetka zgłaszanych szumów usznych do poziomu 8,3\% [4].

Uczestnicy badania przeprowadzonego w latach 1993-1995 i nazwanego Beaver Dam, WI Hearing Loss study to grupa 3737 osób, którą zapytano między innymi o obecność szumów usznych. Klinicznie istotne szumy uszne określono jako dzwonienie, brzęczenie lub inne dźwięki odczuwane w uszach od roku o co najmniej średniej dokuczliwości lub powodujące problemy $\mathrm{z}$ zasypianiem. Badania zostały przeprowadzone wśród osób w wieku od 50. do 80. roku życia. Częstość występowania szumów usznych w grupie wiekowej od 50 do 59 lat wyniosła 7,3\%, a w przedziale wiekowym od 60 do 69 lat wrosła do wartości 10,1\%. Od 70. roku życia zanotowano spadek częstości występowania szumów usznych do poziomu $8,7 \%$ oraz kolejny spadek wartości w grupie 80-latków, gdzie tylko 5,5\% badanych odpowiedziało pozytywnie na pytanie o odczuwanie szumów usznych [5].

Częstość występowania szumów usznych oceniono również w Norwegii, badając w latach 1996-1998 grupę 47410 osób. The Nord Trøndelag Norway Hearing Loss Study to badania kwestionariuszowe przeprowadzone wśród pacjentów, u których wykonano również audiometryczne badanie słuchu. Szumy uszne w kwestionariuszu zostały zdefiniowane jako dokuczliwe dzwonienie w obojgu uszach. Częstość ich występowania w grupie wiekowej od 20 do 29 lat wyniosła 9,8\%. W kolejnych grupach wiekowych odsetek występowania szumów usznych był coraz wyższy, dochodząc do poziomu $24 \%$ w grupie wiekowej od 70 do 79 lat. Wśród osób powyżej 80 roku życia odnotowano spadek częstości występowania szumów usznych do wartości 22,9\%. Opisane wyniki zostały zebrane wśród pacjentów, którzy sami zgłosili się po pomoc z powodu szumów [6].

Z badań przeprowadzonych w Polsce przez Instytut Fizjologii i Patologii Słuchu w latach 1999-2000 wynika, że szumów usznych doświadcza około 20\% Polaków powyżej 18 roku życia. Badania zostały przeprowadzone w trzech wybranych regionach kraju: na Mazowszu, Podlasiu i Śląsku, czyli w regionach zróżnicowanych pod względem uprzemysłowienia i zanieczyszczenia środowiska. Materiał badawczy stanowiła grupa 12000 losowo wybranych osób. Ankiety wypełniał przeszkolony badacz po przeprowadzeniu wywiadu z osobą testowaną. Szumy uszne trwające powyżej 5 minut zgłosiło 20,1\% badanych. Obecność stałych szumów usznych stwierdziło 4,8\% respondentów. Częstość występowania szumów usznych wzrastała wraz $\mathrm{z}$ wiekiem. Wśród osób do 25 roku życia występowanie szumów usznych oceniono na poziomie $9,7 \%$, natomiast w grupie wiekowej powyżej 75 roku życia występowanie szumów usznych stwierdzono u 52,8\% badanych. Stwierdzono statystycznie istotne częstsze występowanie tej dolegliwości u mężczyzn niż u kobiet, $\mathrm{z}$ wyjątkiem grupy wiekowej pomiędzy 35 a 45 rokiem życia, gdzie szumy uszne częściej występowały wśród płci żeńskiej [7]. W badaniach oceniono również występowanie nadwrażliwości słuchowej, którą zgłosiło 15,2\% badanych. Obniżoną tolerancję na głośne dźwięki znacznie częściej zgłaszali mężczyźni (61\%) niż kobiety (39\%). Szumy uszne i nadwrażliwość słuchową jako dolegliwości występujące równocześnie zgłosiło 8\% badanych [8].

Hasson w 2010 roku w Szwecji opublikował wyniki na temat występowania szumów usznych, które zostały zdefiniowane jako słyszenie w ostatnim czasie dźwięków (tak zwanych szumów usznych) trwających powyżej 5 minut. Częstość występowania szumów określono na poziomie 26,2\% w grupie około 10 tysięcy osób aktywnych zawodowo w wieku od 16 do 64 lat. Szumy częściej występowały u mężczyzn niż u kobiet [9].

Kolejne badania o nazwie National Health and Nutrition Survey opublikowane również w 2010 roku zostały przeprowadzone w USA wśród ponad 14 tysięcy osób w wieku powyżej 20 lat. Uczestnicy odpowiadali na pytanie: Czy w ciągu ostatnich 12 miesięcy słyszałeś dzwonienie, brzęczenie, huk w uszach? Uzyskane wyniki były zbliżone do wyżej opisanych - uzyskano $25,3 \%$ odpowiedzi pozytywnych, potwierdzających słyszenie szumów usznych. Częstość występowania szumów wzrastała wraz z wiekiem badanych i w grupie wiekowej pomiędzy 60 a 70 rokiem życia wyniosła $31,4 \%$ [10].

Mc Cormack skoncentrował się na ocenie częstości występowania szumów usznych oraz ich dokuczliwości, 
ze szczególnym uwzględnieniem pacjentów o tzw. osobowości neurotycznej. Neurotyczność została zdefiniowana jako indywidualne różnice $\mathrm{w}$ tendencji do odczuwania m.in. negatywnych emocji - u osób określonych jako osobowość neurotyczna te skłonności były szczególnie widoczne. Dane zostały zebrane za pośrednictwem UK Biobank. Rekrutacja uczestników badania dotyczyła grupy wiekowej pomiędzy 40 a 60 rokiem życia. Łącznie wysłano 9,2 miliona zaproszeń, na które odpowiedziało 503325 uczestników w latach 2006-2010. Badani wypełniali kwestionariusze w jednym z 22 centrów zlokalizowanych w Anglii, Walii i Szkocji. Pytanie na temat szumów zostało sformułowane w następujący sposób: Czy odczuwasz dźwięki takie jak: dzwonienie czy brzęczenie w jednym lub obojgu uszach, które trwają dłużej niż 5 minut? Drugie pytanie było związane z ich dokuczliwością i brzmiało: Jak bardzo szumy uszne martwią Cię, rozdrażniają lub męczą, jeśli się nasilają? Pacjenci wybierali jedną z możliwych odpowiedzi na zadane pytanie o następującej treści: wcale nie martwią, trochę martwią, średnio martwią oraz bardzo martwią. Dwie ostatnie odpowiedzi zostały zakwalifikowane jako szumy natrętne, nieznośne. Do oceny problemów emocjonalnych posłużył kwestionariusz o nazwie Eysenck Personality Inventory (EPI) składający się z trzynastu pytań. $\mathrm{Na}$ pytania związane z odczuwaniem szumów usznych odpowiedziało 172621 osób. Częstość występowania szumów usznych wyniosła 16,2\% (wśród mężczyzn 18,3\%, wśród kobiet 14\%). Dokuczliwe szumy uszne stwierdziło u siebie 3,8\% respondentów. Częstość szumów wzrastała wraz $\mathrm{z}$ wiekiem, osiągając maksymalny odsetek w grupie wiekowej powyżej 65 roku życia - powyżej $25 \%$ u mężczyzn i niecałe $20 \%$ u kobiet. Potwierdzono, że niedosłuch jest czynnikiem predykcyjnym wystąpienia szumów usznych. Wiek badanych nie korelował z dokuczliwością szumów usznych. Kobiety zgłaszały częściej nieznośne szumy uszne (4,12\%) niż mężczyźni (3,52\%). Odczuwanie szumów usznych, zdefiniowanych w badaniu jako nieznośne i natrętne, stwierdzono częściej u osób z dodatnim wynikiem testu, na podstawie którego oceniono je jako neurotyczne [11].

Korea National Health and Nutrition Examination Survey to badania przeprowadzone w latach 2009-2012, które objęły grupę 19290 osób w wieku od 20 do 98 lat. Uczestnicy badania zostali zapytani o słyszenie szumów pod postacią: dzwonienia, syczenia, brzęczenia czy ryku słyszanych w ciszy w okresie ostatniego roku. Słyszenie szumów potwierdziło $20,7 \%$ badanych, z czego u większości z nich $(69,2 \%)$ szumy uszne nie powodowały dyskomfortu. Szumy stwierdzono u mniej niż $20 \%$ osób w wieku od 20 do 49 lat. Począwszy od 50 roku życia, odsetek występowania szumów wzrastał, osiągając maksymalną wartość 36\% wśród osób powyżej 85 roku życia [12]. Wyniki uzyskane przez innych badaczy z Azji wykazały, że 11,9\% badanych w Japonii oraz u 14,5\% badanych w Chinach odczuwa szumy uszne trwające powyżej 5 minut. Co ciekawe o odczuwanie szumów usznych pytano osoby od 11 roku życia $[13,14]$. Większa częstość występowania szumów usznych stwierdzona w badaniu Korea National Health and Nutrition Examination Survey miała związek ze stresem oraz aktualnym stanem bezrobocia. Szumy występowały częściej wśród osób narażonych na hałas zawodowy oraz u żołnierzy, jak również u osób słuchających muzyki przez słuchawki oraz u osób narażonych na hałas rekreacyjny. Osoby z niedosłuchem odczuwały szumy częściej w porównaniu z osobami dobrze słyszącymi. Choroby współistniejące, takie jak: hyperlipidemia, depresja, choroby tarczycy oraz astma oskrzelowa, występowały częściej w grupie osób z szumami usznymi w porównaniu z grupą osób, które nie odczuwały szumów [12].

Wyniki badań przeprowadzonych w Nowej Zelandii i opublikowanych w 2015 roku uzyskano na podstawie informacji telefonicznych zebranych przez Roy Morgan Research Limited w latach 2007-2013. Łączna liczba respondentów wyniosła 69 976. Uczestnicy badania zostali zapytani o to, czy przechodzili w ciągu 12 ostatnich miesięcy wymieniane przez osobę zbierającą wywiad choroby lub dolegliwości. Jedną z możliwych opcji do wyboru było odczuwanie szumów usznych. Występowanie szumów usznych stwierdzono u 5,98\% badanych, częściej wśród mężczyzn niż kobiet (6,45\% i 5,53\%). Wraz z wiekiem obserwowano zwiększanie się odsetka osób odczuwających szumy uszne - od wartości 1,6\% w grupie wiekowej od 14 do 24 lat do 13,5\% u osób powyżej 65 roku życia. Częstość występowania była najwyższa w grupie osób zdefiniowanych jako Europejczycy, a najniższa, wynosząca 1\%, w grupie Azjatów [15].

Wyniki badań, które zostały opublikowane w 2014 roku, dotyczyły obserwacji 4,7 miliona rezydentów poniżej 85 roku życia przebywających na terenie Wielkiej Brytanii w latach 2002-2011. Wyniki zgromadzono na podstawie informacji zebranych w dwóch systemach informatycznych CPRD (Clinical Practice Research Datalink) and HES (Hospital Episode Statistics). Analizie zostały poddane szumy uszne istotne klinicznie. Istotność kliniczna odczuwanych szumów wynikała $\mathrm{z}$ faktu, że pacjenci sami zgłaszali się po pomoc. Rejestracja osób w bazie informatycznej systemu opieki zdrowotnej była możliwa na podstawie rozpoznania postawionego przy wypisie pacjenta ze szpitala (baza HES). Podstawą do rejestracji w bazie CPRD było zarejestrowanie się pacjenta $\mathrm{z}$ szumami usznymi w poradni ogólnej, odbycie wizyty w ciągu kolejnych $28 \mathrm{dni}$ $\mathrm{w}$ poradni audiologicznej lub przeprowadzenie procedury doboru aparatu. W przedstawionych wynikach badań częstość występowania szumów wzrastała wraz z wiekiem, osiągając szczytowe wartości, na poziomie 11,4 przypadków na 10000 rezydentów, w grupie wiekowej pomiędzy 60 a 69 rokiem życia. Nie stwierdzono różnic w występowaniu szumów usznych w zależności od płci. W badaniu oszacowano prawdopodobieństwo pojawienia się 14303 nowych incydentów szumów usznych istotnych klinicznie wśród 26,5 miliona osób będących pod obserwacją, co oznacza potencjalnie 5,4 nowych przypadków na 10000 osób. Na podstawie uzyskanych wyników przewiduje się wystąpienie około 324000 nowych przypadków szumów usznych istotnych klinicznie w Anglii w latach 2012-2021. Autorzy uważają, że duży odsetek osób z szumami usznymi to osoby urodzone w latach 40 . i wczesnych 50 . ubiegłego wieku, w okresie tzw. powojennego baby boomu, które obecnie osiągnęły wiek emerytalny. Większość przypadków szumów usznych istotnych klinicznie była obserwowana w grupie osób o wyższym statusie ekonomicznym, zainteresowanych dalszą diagnostyką zgłaszanego problemu. Badacze podkreślali, że wzrastająca popularność komunikacji przez Internet spowodowała większą świadomość zdrowotną wśród pacjentów. Możliwość pozyskania informacji na temat choroby poprzez fora dyskusyjne, różne formy samopomocy czy wsparcia spowodowały zmianę 
Tabela 1. Wyniki badań przekrojowych na temat częstości występowania szumów usznych u osób dorosłych Table 1. The results of research on the incidence of tinnitus in adults

\begin{tabular}{|c|c|c|c|c|}
\hline Autor & Rok publikacji & Liczba badanych & $\begin{array}{c}\text { Częstość } \\
\text { występowania } \\
\text { szumów }\end{array}$ & $\begin{array}{l}\text { Nazwa badania i lata, } \\
\text { w których prowadzono badania }\end{array}$ \\
\hline Axelsson & 1988 & $\begin{array}{l}n=2556 \\
20-79 \text { lat }\end{array}$ & $14,2 \%$ & Gothenburg, 1989 \\
\hline Ries & 1994 & $\begin{array}{l}n=59343 \\
20-80 \text { lat }\end{array}$ & $8,4 \%$ & US NHIS Hearing Supplement, 1990 \\
\hline Davis & 1995 & $\begin{array}{l}n=34050 \\
20-80 \text { lat }\end{array}$ & $10,2 \%$ & $\begin{array}{l}\text { United Kingdom National Study of } \\
\text { Hearing, 1980-1986 }\end{array}$ \\
\hline Adams & 1995 & $\begin{array}{l}n=99453 \\
20-80 \text { lat }\end{array}$ & $4,4 \%$ & US Disability Supplement, 1994-1995 \\
\hline Fabijańska & 1999 & $\begin{array}{l}n=12000 \\
18-75 \text { lat }\end{array}$ & $20,1 \%$ & $\begin{array}{l}\text { Instytut Fizjologii i Patologii Słuchu, } \\
1999\end{array}$ \\
\hline Nondahl & 2002 & $\begin{array}{l}\mathrm{n}=3737 \\
50-80 \text { lat }\end{array}$ & $8 \%$ & $\begin{array}{l}\text { Beaver Dam Hearing Loss Study, } \\
\text { 1993-1995 }\end{array}$ \\
\hline Tambs & 2003 & $\begin{array}{l}n=47420 \\
20-80 \text { lat }\end{array}$ & $15,1 \%$ & $\begin{array}{l}\text { Nord Trøndelag, Norway Hearing Loss } \\
\text { Study, 1996-1998 }\end{array}$ \\
\hline Hasson & 2010 & $\begin{array}{l}\mathrm{n}=9569 \\
16-64 \text { lat }\end{array}$ & $26,2 \%$ & Swedish Work Environment Survey \\
\hline Shargorodsky & 2010 & $\begin{array}{l}\mathrm{n}=14178 \\
20-80 \text { lat }\end{array}$ & $25,3 \%$ & $\begin{array}{l}\text { National Health and Nutrition } \\
\text { Examination Survey }\end{array}$ \\
\hline Kim & 2014 & $\begin{array}{l}n=19290 \\
20-98 \text { lat }\end{array}$ & $20,7 \%$ & $\begin{array}{l}\text { Korea Nutrition Health and Examination } \\
\text { Survey }\end{array}$ \\
\hline Mc Cormack & 2014 & $\begin{array}{c}n=172621 \\
40-69 \text { lat }\end{array}$ & $16,2 \%$ & UK Biobank Study \\
\hline
\end{tabular}

relacji pomiędzy pacjentem a lekarzem, gdyż pacjent zaczyna być stroną aktywną. W publikacji wskazywano na coraz wyższe oczekiwania osób należących do obecnego pokolenia żyjącego w Wielkiej Brytanii, które są beneficjentami coraz większej liczby powstających instytucji mających pomagać pacjentom z szumami usznymi [16].

Wyniki omówionych badań przedstawiono w tabeli 1 .

\section{Dyskusja}

Rezultaty przeprowadzonych badań wskazują, że odsetek występowania szumów usznych wzrasta wraz z wiekiem. Wyniki oceniające częstość występowania szumów usznych u osób młodych, w przedziale wiekowym od 17 do 29 roku życia, w większości mieszczą się w zakresie od $4,7 \%$ do $5,7 \%[1-3,5,6]$. Najniższy odsetek odczuwanych szumów usznych stwierdzono w USA (US National Health International Survey Disability Supplement Study - Phase I), gdzie występowanie szumów usznych $\mathrm{w}$ omawianej grupie wiekowej oceniono na poziomie $1,4 \%$, oraz w Nowej Zelandii - 1,6\% badanych $[4,15]$. Najwyższy odsetek odczuwanych szumów usznych, na poziomie $9,7 \%$, w grupie młodych dorosłych uzyskano w badaniach przeprowadzonych w Polsce oraz w Norwegii, gdzie odsetek pacjentów zgłaszających szumy uszne wyniósł 9,8\% i dotyczył grupy osób, które same zgłosiły się po pomoc $[7,6]$. W prezentowanych wynikach częstość występowania szumów usznych wzrasta wraz $z$ wiekiem badanych (ocenianych zazwyczaj w dziesięcioletnich przedziałach wiekowych) do poziomu pomiędzy $13,3 \%$ a $35 \%$ dla grupy wiekowej $70-$ 79 rok życia $[1-3,5,6,11,12,15]$. W wynikach badań przeprowadzonych w Polsce odsetek występowania szumów usznych wśród osób po 75 roku życia wynosi 52,8\% i jest najwyższy z dotychczas opublikowanych danych [7]. Po 70 roku życia [5] lub wg innych autorów po 80 roku życia $[1-4,12]$ częstość występowania szumów usznych spada do wartości od 5,5\% do 30\%. Zmniejszenie częstości występowania szumów usznych w grupie wiekowej powyżej 70 czy 80 roku życia wynika prawdopodobnie ze zwiększonej umieralności.

Część zespołów badawczych koncentrowała się tylko na ocenie występowania szumów usznych wśród osób starszych. W przeprowadzonych w Australii badaniach o nazwie Blue Mountains Hearing Study, w których liczba badanych wyniosła 2015, stwierdzono występowanie szumów usznych u 30,3\% osób w wieku od 55 do 99 lat [17]. Natomiast wyniki badań zrealizowanych w Japonii i Nigerii wykazały występowanie szumów usznych u osób starszych, powyżej 65 roku życia, odpowiednio na poziomie $18,6 \%$ i $14,1 \%[18,19]$.

Nie ma zgodności w piśmiennictwie na temat ewentualnej dominacji występowania szumów usznych wśród którejś płci. Wyniki badań w USA, Południowej Korei czy Brazylii wskazują na częstsze występowanie szumów usznych u kobiet [10,20,21]. Z kolei publikacje z Polski, Szwecji, USA, Anglii czy ostatnio również z Nowej Zelandii potwierdziły wyższy odsetek występowania szumów usznych u mężczyzn [7,9-11,15]. Autorzy tacy jak Michikawa, Martinez czy Lasisi nie stwierdzili przewagi występowania szumów usznych wśród płci męskiej czy żeńskiej [16,18,19]. Mc Cormack uważa, że szumy częściej występują u mężczyzn, ale to właśnie kobiety oceniają szumy uszne jako bardziej dokuczliwe [11]. 
W większości cytowane publikacje były badaniami przekrojowymi i opierały się na ocenie częstości występowania szumów usznych w badanej populacji. Beaver Dam Study (Wisconsin) oraz Blue Mountain Hearing Study (Sydney) są prospektywnymi studiami kohortowymi, które oszacowały długoterminowe ryzyko wystąpienia szumów usznych w populacji $[5,22,23]$. Nondahl określił ryzyko pojawienia się szumów w okresie 5-letnim w grupie 2922 starszych dorosłych na poziomie 5,7\%, a w okresie 10 -letnim na poziomie $12,7 \%$ [5,22]. Z kolei w Blue Mountain Hearing Study prawdopodobieństwo nowych zdarzeń szumów usznych w grupie 612 pacjentów dorosłych wyniosło $18 \%$ [23]. Kolejne badania kohortowe opublikowane przez Martineza w 2014 roku wskazują, na podstawie obserwacji retrospektywnych w ciągu 10 poprzednich lat, na 258000 nowych przypadków pacjentów z szumami usznymi. Szacuje się wystąpienie 324000 nowych przypadków klinicznie istotnych szumów usznych jako wynik obserwacji wzrostu zachorowań w latach 2002-2011 [16]. Przewaga badań kohortowych nad przekrojowymi polega na tym, że pozwalają one na podstawie wyników badań retrospektywnych na szacowanie ryzyka wystąpienia nowych przypadków szumów usznych w przyszłości. Obecnie podkreśla się potrzebę oceny częstości występowania szumów usznych tak zwanych istotnych klinicznie, czyli takich, które są dokuczliwe czy też martwią pacjenta na tyle, że zgłasza się on $\mathrm{z}$ ich powodu po pomoc. Natomiast dla raportów epidemiologicznych za szumy istotne klinicznie uznaje się takie, które trwają powyżej 5 minut.

\section{Wnioski}

Analiza piśmiennictwa wskazuje na wzrost częstości występowania szumów usznych wraz $\mathrm{z}$ wiekiem badanych osób. Prezentowane wyniki badań szacujących ryzyko wystąpienia szumów usznych w przyszłości wskazują, że liczba pacjentów $\mathrm{z}$ tym problemem będzie wzrastać. Wydaje się, że diagnostyka i leczenie szumów usznych będzie zatem stanowić istotne wyzwanie dla systemu opieki zdrowotnej, szczególnie w państwach, których społeczeństwa się starzeją.

Artykuł powstał $w$ zwiazku $z$ realizacja projektu „Zintegrowany system narzędzi do diagnostyki i telerehabilitacji schorzeń narzadów zmysłów (słuchu, wzroku, mowy, równowagi, smaku, powonienia)" wspólfinansowanego przez Narodowe Centrum Badań i Rozwoju w ramach Programu STRATEGMED.

\section{Piśmiennictwo:}

1. Davis A. Hearing in adults. The prevalence and distribution of hearing impairment and reported hearing disability, in MRS Institute of Hearing Research National Study of Hearing. London: Whurr Publishers Ltd.; 1995.

2. Axelsson A, Ringdahl A. Tinnitus-a study of its prevalence and characteristics. Br J Audiol, 1989; 23: 53-62.

3. Ries P. Prevalence and characteristics of persons with hearing trouble: United States, 1990-1991, in Vital and health statistics. Hyattsville (MD): National Centre for Health Statistics; 1994.

4. Adams P, Marano M. Current estimates from the National Health Interview Survey, in Vital and health statistics. Hyattsville (MD): National Centre for Health Statistics; 1995.

5. Nondahl D, Cruickhanks K, Wiley T. Prevalence and 5 year incidence of tinnitus among older adults: the epidemiology of hearing loss study. J Am Acad Audiol, 2002; 13: 321-23.

6. Tambs K, Hoffman H, Borchgrevink H i wsp. Hearing loss induced by noise, ear infections and head injuries: results from the Nord-Trondelag Hearing Loss Study. Int J Audiol, 2003; 42: 89-105.

7. Fabijańska A, Rogowski M, Bartnik G, Skarżyński H. Epidemiology of tinnitus and hyperacusis in Poland. W: Hazell JPW, red. Proceedings of the Sixth International Tinnitus Seminar. London: The Tinnitus and Hyperacusis Centre; 1999, 569-71.

8. Skarżyński H, Rogowski M, Fabijańska A, Bartnik G, Raj-Koziak D. The epidemiology of hearing disorders in Poland. W: Jahnke K, Fischer M, red. $4^{\text {th }}$ European Congress of Oto- Rhino-Laryngology Head and Neck Surgery (Berlin 2000). Monduzzi Editore, 2000; 159-63.

9. Hasson D, Theorell T, Westerlund H i wsp. Prevalence and characteristics of hearing problems in a working and non working Swedish population. J Epidemiol Community Health, 2010; 64(5): 453-60.

10. Shargorodsky J, Curhan GC, Farwell WR. Prevalence and characteristics of tinnitus among US adults. Am J Med, 2010; 123(8): 711-18.
11. Mc Cormack A, Edmondson-Jones M, Fortnum H, Dawes P, Middleton H, Munro KJ, Moore DR. The prevalence of tinnitus and the relationship with neuroticism in a middle-aged UK population. J Psychosom Res, 2014; 76: 56-60.

12. Kim H, Lee H, An S, Sim S, Park B, Kim SW i wsp. Analysis of prevalence and associated risk factors of tinnitus in adults. PLoS One, PLoS One, 2015; 10(5): e0127578.

13. Fujii K, Nagata C, Nakamura K, Kawachi T, Takatsuka N, Oba S i wsp. Prevalence of tinnitus in community-dwelling Japenese adults. J Epidemiol, 2011; 21: 299-304.

14. Xu X, Bu X, Zhou L, Xing G, Liu C, Wang D. An epidemiologic study of tinnitus in a population in Jiangsu Province, China. J Am Acad Audiol, 2011; 22: 578-85.

15. Wu B, Searchfield G, Exeter D, Lee A. Tinnitus prevalence in New Zeland. N Z Med. J, 2015; 128(1424): 23-34.

16. Martinez C, Wallenhorst Ch, Mc Ferran D, Hall DA. Incidence rates of clinically significant tinnitus: 10 year trend from a cohort study in England. Ear Hear, 2014; 36(3): 69-75.

17. Sindhusake D, Mitchell P, Newall P, Golding M, Rochtchina E, Rubin G. Prevalence et characteristics of tinitus in older adults. The Blue Mountain Hearing Study. Int J Audiol, 2003; 42(5): 289-94.

18. Michikawa T, Nishiwaki Y, Kikuchi Y, Saito H, Mizutari K, Okamoto $\mathrm{M}$ i wsp. Prevalence and factors associated with tinnitus: a community-based study of Japanese elders. J Epidemiol, 2010; 20(4): 271-76.

19. Lasisi AO, Abiona T, Gureje O. Tinnitus in the elderly. Profile, correlations and impact in the Nigerian study of ageing. Otolaryngol Head Neck Surg, 2010; 143(4): 510-15.

20. Park KH, Lee SH, Koo JW, Park HY, Lee KY, Choi YS i wsp. Prevalence and associated factors of tinnitus; Data from the Korean National Health and Nutrition examination survey 2009-2011. J Epidemiol, 2014; 24(5): 417-26.

21. Oiticica J, Bittar RS. Tinnitus prevalence in the city of São Paolo. Braz J Otorhinolaryngol, 2015; 81(2): 167-76. 
22. Nondahl DM, Cruickshanks KJ, Wiley TL, Klein BE, Klein R, Chappell $\mathrm{R}$ i wsp. The 10-year incidence of tinnitus among older adults. Int J Audiol, 2010; 49: 580-85.
23. Gopinath B, McMahon CM, Rochtchina E, Karpa MJ, Mitchell P. Incidence, persistence and progression of tinnitus symptoms in older adults. The Blue Mountain hearing study. Ear Hear, 2010; 31: 407-12. 